Article

\title{
Subjective Well-Being in Higher Education: Psychometric Properties of the Satisfaction with Life and Subjective Vitality Scales in Spanish University Students
}

\author{
Laura Delgado-Lobete ${ }^{1,+}+{ }^{\infty}$, Rebeca Montes-Montes ${ }^{2, *,+}\left(\mathbb{D}\right.$, Alba Vila-Paz ${ }^{1}$, \\ Miguel-Ángel Talavera-Valverde ${ }^{1}{ }^{10}$, José-Manuel Cruz-Valiño ${ }^{1,3}$, Berta Gándara-Gafo ${ }^{1}$, \\ Adriana Ávila-Álvarez ${ }^{4}$ and Sergio Santos-del-Riego ${ }^{1,5}$ (D) \\ 1 Health Integration and Promotion Research Unit (INTEGRA SAÚDE), Faculty of Health Sciences, University \\ of A Coruña, 15006 A Coruña, Spain; 1.delgado@udc.es (L.D.-L.); alba.vila1@udc.es (A.V.-P.); \\ miguel.angel.talavera.valverde@udc.es (M.-Á.T.-V.); director@iciro.es (J.-M.C.-V.); \\ berta.gandara.gafo@udc.es (B.G.-G.); sergio.santos.delriego@udc.es (S.S.-d.-R.) \\ 2 TALIONIS Research Group, Faculty of Health Sciences, University of A Coruña, 15008 A Coruña, Spain \\ 3 Institute for Oral Implantology and Rehabilitation of A Coruña (Instituto Coruñés de Implantología y \\ Rehabilitación Oral-ICIRO), 15007 A Coruña, Spain \\ 4 Faculty of Health Sciences, University of A Coruña, 15008 A Coruña, Spain; adriana.avila.alvarez@udc.es \\ 5 Health Promotion Department, University of A Coruña, 15011 A Coruña, Spain \\ * Correspondence: rebeca.montes@udc.es; Tel.: +34-881-014-339 \\ + Both authors contributed equally to the study.
}

Received: 24 February 2020; Accepted: 4 March 2020; Published: 11 March 2020

\begin{abstract}
Satisfaction with life (SWL) and subjective vitality (SV) are indicators of subjective well-being and quality of life. University students are at risk of low levels of subjective well-being, and therefore it is necessary to have properly validated tools to assess SWL and SV in this population. The aim of this study was to test the psychometric properties of the satisfaction with life scale (SWLS) and subjective vitality scale (SVS) in Spanish university students. Participants were 435 undergraduate students enrolled in 50 different courses $(\mathrm{M}=20.9$ years, $\mathrm{SD}=2.1$; female students $=71.2 \%)$. Confirmatory factor analysis (CFA) was used to test the structure of the scales. Internal consistency, criterion and discriminant validity were also evaluated. Results confirmed the 5-item model of the SWLS $(\mathrm{NNFI}=0.975, \mathrm{CFI}=0.987, \mathrm{RMSEA}=0.076)$ and the six-item model of the SVS (NNFI $=0.980$, CFI $=0.988$, RMSEA $=0.102$ ). Internal consistency was excellent in both scales. The SWLS and the SVS were significantly associated, and students with low self-esteem showed lower SWL and SV, indicating good criterion and discriminant validity. These findings support the use of the SWLS and SVS for the assessment of subjective well-being in higher education context.
\end{abstract}

Keywords: subjective well-being; subjective vitality; satisfaction with life; factor structure; validity; reliability; confirmatory factor analysis; higher education; university students

\section{Introduction}

Subjective well-being has become a topic of major interest in sustainability research and psychosocial and public health [1-3]. Subjective well-being is a comprehensive concept that refers to multiple self-evaluations of overall life and is composed of both cognitive and emotional constructs [4-7]. While the later factor refers to emotional, short-term experiences, the cognitive aspect of subjective well-being focuses on a more stable perspective of life. Satisfaction with life is considered the cognitive component of subjective well-being as it entails the person's evaluation of their life as a whole in relation 
to their ideal life [4]. Positive affect and negative affect (affective subjective well-being) comprise positive states (i.e., enthusiastic and active feelings) and negative states (i.e., such as distress, anger or fear), respectively [8]. A person with high levels of subjective well-being will report a global sense of satisfaction with life alongside high rates of positive affect, in contrast to low rates of negative affect [9].

Subjective well-being is one of the most important determinants of life fulfillment and quality of life, and heavily associates with mental and psychosocial health $[10,11]$. Research demonstrates that subjective well-being clearly contributes to health and longevity [12]. For instance, young adults that presented high levels of affective subjective well-being during adolescence suffer fewer psychosocial issues and show healthier adjustment to adulthood, as well as higher levels of work functioning and increased self-worth [13]. Subjective well-being is also associated with resilience, healthy lifestyles and perceived health in university students $[14,15]$. Higher education students with low levels of subjective well-being are more likely to present depression, anxiety and stress [16]. Self-esteem is also closely associated with well-being, as high self-esteem is one of the strongest indicators of subjective well-being $[4,17,18]$.

In recent years, several studies have further explored the link between subjective well-being and social, economic and environmental sustainability, and there is an increasing interest in exploring the relationship between sustainability and quality of life [19-25]. For instance, Musa et al. [25] designed a new instrument aimed to measure community well-being that fully integrated ecological, economic and social sustainability and found a significant relationship between the level of well-being and sustainable urban development, especially focusing on social sustainability. Findings from a recent study carried out in Spain suggest that excess of concern for material and economic pursuit is associated with lower levels of happiness and well-being and undermines social sustainability [19].

During the last decade, research has focused particularly on subjective well-being in university students, as worrying low levels of both cognitive and affective subjective well-being have been reported in this population [26-29]. Additionally, this population is more likely to suffer high levels of stress, depression and anxiety, which severely affect their subjective well-being and quality of life [30-32]. Among university students, the link between sustainability and subjective well-being is of particular interest, because higher education has been proposed as a predictor of post-materialistic goals and green values [1,33], and conflict between green and materialistic values is associated with higher degrees of stress and a lower subjective well-being [22]. Additionally, although university students consider psychosocial and social sustainability in particular core factors of subjective well-being, research regarding this topic is scarce $[1,34,35]$.

Several factors contribute to explain the low levels of subjective well-being in higher education, but educational context plays an especially relevant role in students' experience of well-being [29,36]. Resources provided by the university, both structural and institutional, are important predictors of subjective well-being and quality of life in higher education [36].

In order to understand the underlying factors that interrelate with subjective well-being and to prompt interventions aimed to promote quality of life in university students, it is necessary to adequately assess both cognitive and affective subjective well-being. Cognitive and affective components of well-being associate with different outcomes, and therefore different assessment instruments are needed to address each construct [37-39].

The satisfaction with life scale (SWLS) [40] is the most commonly used measure to evaluate overall life satisfaction as the cognitive aspect of subjective well-being, both in the general population and in university students [40-45]. Its psychometric properties have been extensively tested in different cultural contexts and populations, including Spanish adolescents and adults [37,46-49].

Subjective vitality refers to the self-conscious experience of energy and aliveness, and it has been used to assess the positive affective component of subjective well-being [50-52]. The subjective vitality scale (SVS) [50] was developed to measure this construct and has been widely used across different cultural contexts and populations, including with university students [50,51,53-56]. At least three versions of the SVS have been employed to assess subjective vitality. The original seven-item model 
scale initially developed by Ryan and Frederick [50]; the six-item model proposed by Bostic et al. [57] with item two removed; and a five-item model scale, with items two and five removed, as proposed by Kawabata et al. [58] The SVS has been cross-culturally adapted and validated in Spanish adolescents by Castillo et al. [59], who found that the 6-item version of the SVS (without item 2) had the best fit in Spanish population.

Overall, the SWLS and the SVS are widely used and well validated instruments to measure the cognitive and affective aspects of subjective well-being. However, to the best of our knowledge, the SWLS and the SVS have not been validated in Spanish university students. As satisfaction with life and subjective vitality are commonly addressed to evaluate well-being, it is necessary to have properly validated tools to ensure that these constructs are adequately measured. Findings from previous studies show that validation of both the satisfaction with life scale and the subjective vitality scales in university students is relevant and a frequent research concern even when a previous validation in general population existed within the same country [56,60-63]. Moreover, invariance between university students and other adults has been reported within the same country, thus making it necessary to pay careful attention when comparing different groups [63].

As higher education students are at risk of low well-being, it is necessary to test the psychometric properties of the SWLS and the SVS in this population. Therefore, the aim of this study was to examine the reliability, factor structure and criterion and discriminant validity of the SWLS and the SVS in Spanish university students.

\section{Materials and Methods}

\subsection{Procedure and Participants}

Ethical approval was obtained from the Ethics Committee of the University of A Coruña prior to data collection (code 20180201). Participation in the study was voluntary, and all participants consented to take part anonymously and confidentially. A sample size of at least 200 participants was needed in order to conduct a confirmatory factor analysis (CFA) achieving minimal bias $(<0.05)$ and a statistical power of 0.99 , considering that both SWLS and SVS have a one-factor structure [64].

Questionnaires were distributed online to all students enrolled in undergraduate programs at University of A Coruña (northwestern Spain). An informative email was sent to all students' institutional emails from February to June 2018, so that every student could participate in the study if desired. A total of 13,681 undergraduate students received the invitation to participate in the study, and only completely fulfilled questionnaires were registered and included in the final sample in order to avoid missing values. Students had to read the information about the study and agree to participate in order to get access to the questionnaires.

The final sample comprised 435 undergraduate students from 40 different academic programs who fully completed the survey package of the study. Participants' average age was 21.4 years $(\mathrm{SD}=3.01)$, and $70.1 \%$ were women. Most of the students lived in urban areas (54.3\%), while $26.2 \%$ and $19.5 \%$ lived in suburban and rural areas, respectively. With regard to field of study, $39.5 \%(n=172)$ were pursuing a technical/scientist degree, $34.5 \%(n=150)$ were enrolled in social/legal sciences courses, $20.7 \%(n=90)$ were pursuing a health sciences degree and $5.3 \%(n=23)$ were enrolled in arts/humanities courses. Additionally, $26.7 \%(n=116)$ were first-year students, $24.8 \%(n=108)$ were second-year students, $19.3 \%(n=84)$ were third-year students, $22.3 \%(n=97)$ were fourth-year students and $6.9 \%(n=30)$ were fifth-year students.

\subsection{Measures}

\subsubsection{Satisfaction with Life Scale}

The SWLS is a 5-item self-report that assesses cognitive judgments of global satisfaction with different aspects of life [40]. Two scales of response for the Spanish version of the SWLS have been 
proposed: the 5-point and the 7-point Likert scales [37,46-49]. In this study, we used the 5-point version, which ranges from 1 (strongly disagree) to 5 (strongly agree) and has been previously used in Spanish adolescents and elderly adults [46-49]. An example of the items of the SWLS is: In most ways my life is close to my ideal (item 1). The SWLS has been adapted and validated in Spanish adolescents, adults and elderly adults, further confirming its unidimensional structure and good psychometric properties (Cronbach's alpha: adolescents $=0.84$; adults and elderly adults $=0.88)[37,46]$.

\subsubsection{Subjective Vitality Scale}

The 6-item Spanish version of the SVS was used in this study [59]. The SVS is a self-report questionnaire that measures the subjective experience of being full of energy and alive using a 7-point Likert scale from 1 (not at all true) to 7 (very true) [50]. An example of the items of the SVS is: I feel alive and full of vitality (item 1 ).

The SVS was validated in Spain using a sample of 790 Spanish adolescents [59]. The final Spanish version uses the 6-item model, as the deletion of item 2 (I don't feel very energetic) provided a better fitting model for the data [57,59]. The Spanish version of the SVS showed a good fitting to the unidimensional structure and excellent psychometric properties in adolescents (Cronbach's alpha $=0.84-0.86)[59]$.

\subsubsection{Rosenberg Self-Esteem Scale}

The Spanish version of the RSES was used to provide evidence of the discriminant validity of the SWLS and SVS in Spanish university students $[65,66]$. The RSES is a 10-item questionnaire that assess self-esteem on a 4-point Likert scale from 1 (strongly disagree) to 4 (strongly agree). An example of the items of the RSES is: On the whole, I am satisfied with myself (item 1).

The responses are summed to provide a total score ranging from 10 to 40 , where higher scores are considered to indicate good self-esteem. The RSES has been widely validated across different cultural contexts and populations [66].

The Spanish version of the RSES has been validated in Spanish university students showing excellent psychometric properties (Cronbach's alpha $=0.85-0.88$; test-retest correlation $=0.84$ ) [66]. A cut-off below 25 points on the total scale is indicator of low self-esteem [67].

\subsection{Statistical Analysis}

Statistical analyses were conducted with SPSS 20.0 and EQS 6.1 for Windows. Internal consistency of the SWLS and the SVS was examined. A Cronbach's alpha value higher than 0.70 was considered an indication of good internal consistency.

Considering the ordinal nature of the items in both scales, we performed a confirmatory factor analysis (CFA), using a robust unweighted least squares estimation method to test the factor structure of the SWLS and the SVS in Spanish higher education [68-70]. A robust root mean square error of approximation (RMSEA) of $<0.08$, a robust comparative fit index (CFI) of $>0.95$ and a robust non-normed fit index (NNFI) of $>0.95$ were indicators that the model fitted the data acceptably [71,72]. As the $X^{2}$ is very sensitive to sample size and when analyzing self-report questionnaires $[37,59,73,74]$, the value of Satorra-Bentler $X^{2} / \mathrm{df}$ was used with values less than 5.0 , and this was considered to be acceptable [71,75]. Two models were assessed for the SVS: the 6-item model [57,59], and the 5-item model [58,76]. The original 5-item model of the SWLS was examined [40].

Finally, the criterion validity of the SWLS and the SVS was addressed using Pearson's bivariate correlations between both scales. Differences in SWL and SV between students with high and low self-esteem were calculated to test the discriminant validity of the SWLS and the SVS. 


\section{Results}

\subsection{Demographic Data and Internal Consistency Reliability}

The descriptive statistics and Cronbach's alpha coefficient of the SWLS and the two models of the SVS are presented in Table 1. Skewness and kurtosis of all items and total scores were between -2 and +2 [77-79]. The estimates of internal consistency of the SVS six-item model were slightly higher.

Table 1. Descriptive and reliability analysis of the satisfaction with life scale (SWLS) and the subjective vitality scale (SVS) $(n=435)$.

\begin{tabular}{ccccccc}
\hline Scales & Range & M & SD & Skewness & Kurtosis & Cronbach's Alpha \\
\hline SWLS & & & & & & \\
Item 1 & $1-5$ & 3.3 & 1.0 & -0.4 & -0.3 & \\
Item 2 & $1-5$ & 3.5 & 1.1 & -0.4 & -0.5 & \\
Item 3 & $1-5$ & 3.6 & 1.0 & -0.7 & 0.2 & \\
Item 4 & $1-5$ & 3.6 & 1.0 & -0.5 & -0.4 & \\
Item 5 & $1-5$ & 2.8 & 1.2 & 0.2 & -0.9 & \\
Total score & $5-25$ & 16.8 & 4.2 & -0.4 & -0.2 & \\
SVS & & & & & & \\
Item 1 & $1-7$ & 5.0 & 1.8 & -0.5 & -1.0 & \\
Item 3 & $1-7$ & 3.9 & 1.9 & 0.0 & -1.1 & \\
Item 4 & $1-7$ & 4.6 & 1.7 & -0.4 & -0.8 & \\
Item 5 & $1-7$ & 3.8 & 1.7 & -0.1 & -0.8 & \\
Item 6 & $1-7$ & 3.8 & 1.7 & 0.0 & -0.9 & \\
Item 7 & $1-7$ & 3.9 & 1.7 & 0.0 & -0.9 & \\
Total score (6-item) & $6-42$ & 25.1 & 9.2 & -0.3 & -0.9 & \\
Total score (5-item) & $5-35$ & 21.3 & 7.7 & -0.3 & -0.9 & \\
\hline
\end{tabular}

$\mathrm{M}=$ mean; $\mathrm{SD}=$ standard deviation .

\subsection{Factor Structure}

The model fit indices for the SWLS and the two SVS models are showed in Table 2. The original five-item model of the SWLS demonstrated a good fit to the data. All the fit indices were below or above the acceptable criteria. The SWLS standardized item factor loadings were statistically significant and ranged from 0.62 to 0.85 (Figure 1).
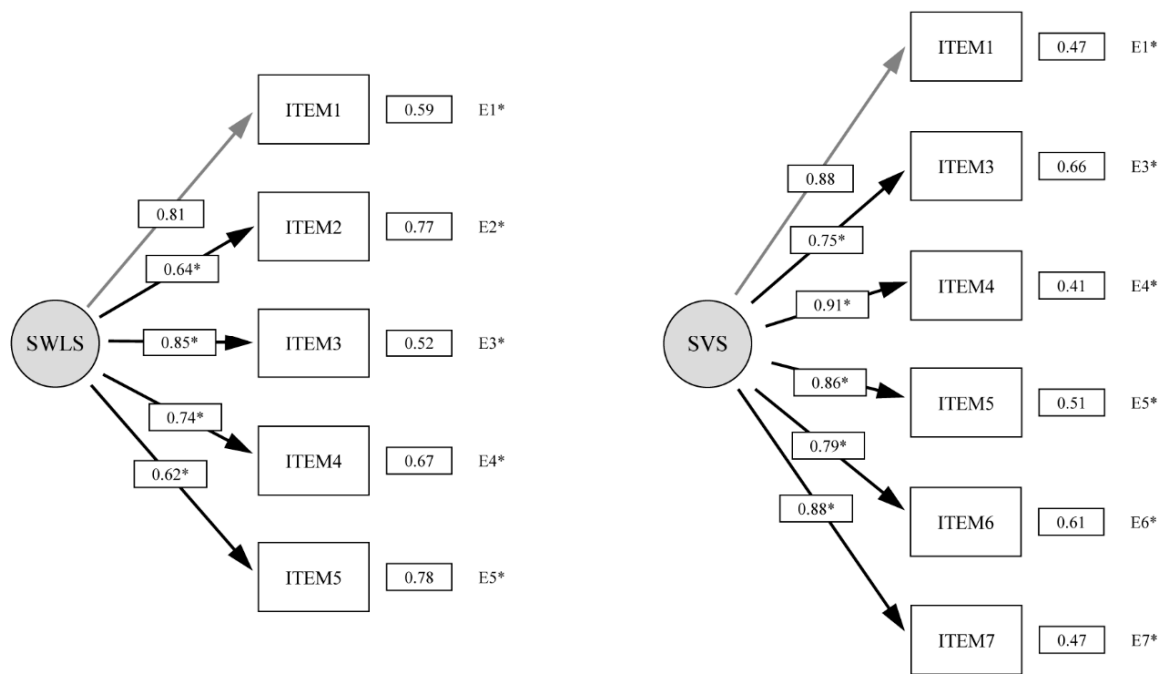

Figure 1. Confirmatory factor analysis (CFA) of the satisfaction with life scale (SWLS) and the subjective vitality scale (SVS) (6-item model) in university students $(n=435)$. Item 1 fixed to 1 during estimation. $*=p<0.05 ; \mathrm{E}=$ residual variances. 
Table 2. Fit indices for the SWLS and SVS models $(n=435)$.

\begin{tabular}{ccccccc}
\hline Model & S-B $\mathbf{X}^{\mathbf{2}}$ & $\mathbf{d f}$ & $\mathbf{X}^{\mathbf{2}} / \mathbf{d f}$ & RMSEA (90\% CI) & NNFI & CFI \\
\hline SWLS (5-item) & 17.45 & 5 & 3.49 & $0.076(0.039-0.116)$ & 0.975 & 0.987 \\
SVS (6-item) & 49.81 & 9 & 5.53 & $0.102(0.075-0.131)$ & 0.980 & 0.988 \\
SVS (5-item) & 37.70 & 5 & 7.54 & $0.123(0.088-0.161)$ & 0.971 & 0.986 \\
\hline S-B X ${ }^{2}$ = Satorra-Bentler X ${ }^{2} ;$ RMSEA = robust root mean-square error of approximation; NNFI = robust non-normed \\
fit index; CFI = robust comparative fit index.
\end{tabular}

Regarding the SVS factor structure, the six-item model had a better fit than the five-item model, although RMSEA and $\mathrm{X}^{2} / \mathrm{df}$ values were slightly high (Table 2). However, NNFI and CFI values were optimal, indicating an overall acceptable fit. The standardized factor loadings of the six-item model were significant and ranging from 0.75 to 0.91 (Figure 1).

\subsection{Criterion and Discriminant Validity}

Satisfaction with life, as measured with the SWLS, and subjective vitality, measured with the six-item SVS, were both positively, moderately and significantly correlated, indicating support for the criterion validity of both scales $(\mathrm{r}=0.433, p<0.001)$.

University students with low self-esteem, as measured by the RSES, scored significant lower in SWLS and SVS items and total scores, supporting the discriminant validity of both scales in Spanish higher education students (Table 3).

Table 3. Differences in SWLS and SVS (six-item model) item and total scores across students with low and high self-esteem $(n=435)$.

\begin{tabular}{cccc}
\hline Scales & Low Self-Esteem $n=82$ & High Self-Esteem $n=353$ & \\
\hline Mean (SD) & Mean (SD) & \\
\hline SWLS & & & \\
Item 1 & $2.5(1.0)$ & $3.5(0.8)$ & $<0.001$ \\
Item 2 & $3.1(1.1)$ & $3.6(1.0)$ & $<0.001$ \\
Item 3 & $2.7(1.0)$ & $3.8(0.8)$ & $<0.001$ \\
Item 4 & $2.7(1.1)$ & $3.8(0.9)$ & $<0.001$ \\
Item 5 & $2.2(1.2)$ & $3.0(1.2)$ & $<0.001$ \\
Total score & $13.1(4.2)$ & $17.7(3.7)$ & \\
SVS & & & $<0.001$ \\
Item 1 & $3.7(1.5)$ & $5.3(1.7)$ & $<0.001$ \\
Item 3 & $2.8(1.7)$ & $4.2(1.9)$ & $<0.001$ \\
Item 4 & $3.5(1.6)$ & $4.9(1.7)$ & $<0.001$ \\
Item 5 & $2.8(1.6)$ & $4.1(1.6)$ & $<0.001$ \\
Item 6 & $2.9(1.6)$ & $4.0(1.6)$ & $<0.001$ \\
Item 7 & $2.6(1.4)$ & $4.2(1.6)$ & $<0.001$ \\
\hline Total score (6-item) & $18.4(7.8)$ & $26.7(8.7)$ & \\
\hline
\end{tabular}

Student $t$-test; $\mathrm{M}=$ mean; $\mathrm{SD}=$ standard deviation.

\section{Discussion}

The aim of this study was to examine the psychometric properties of two widely used instruments to measure cognitive and affective components of subjective well-being in Spanish university students: the Spanish versions of the SWLS and the SVS.

In line with previous research in different cultural contexts and populations, a single-factor solution model for the SWLS revealed a good fit. The factor structure of SWLS has been widely confirmed in previous research across different cultural contexts and populations, including Spanish, German, Chilean, Mexican, Korean, Italian and Israeli adults [37,45,60,61,63,80,81], and Mexican, Mexican-American, Korean, Togolese, Czech, Brazilian, American, Chilean and Turkish higher 
education students $[56,62,63,82-87]$. These findings provide further support of the cross-cultural invariance of the SWLS and add to the growing body of knowledge about well-being assessment in college students. Additionally, the SWLS showed excellent internal consistency reliability in Spanish university students, overall indicating that this scale is a reliable and valid measure to address satisfaction with life in a higher education context.

Consistent with the model proposed by Bostic et al. [57], results of the CFA supported the hypothesized unidimensional structure of the SVS. The six-item model has been previously tested with a sample of Spanish adolescents [59], showing a good fit to the data, and this model has been widely used in different populations in Europe and China [88-90].

A five-item model of the SVS has been recently proposed and used in Japanese, Singaporean and Chinese populations [58,76], arguing that the deletion of item five (I look forward to each new day) provides a better fit. In this study, CFA supported the six-item model over the five-item model in university students, which is in line with the findings from the Spanish cross-cultural adaptation and validation of the SVS [59]. These outcomes could mean that the Spanish population considers the feeling of looking forward to each new day as an indicator of subjective vitality, suggesting a potential cross-cultural variance of subjective well-being between western and eastern populations. Internal reliability of the six-item version was slightly higher as well, which further supports the use of the six-item model within the Spanish context.

It should be noted that the RMSEA value of the SVS six-item model was above the recommended cut-off, but close to 0.10 , which may be considered a reasonable value in models with small df if the other goodness-of-fit indices are good [91], which is the case of the present study. Considering that factor loading values were optimal, and that the NNFI and CFI values were well above the recommended cut-off criteria, this study yielded an overall acceptable fit to the data.

Criterion validity analysis showed a moderate and significant correlation between the SWLS and the SVS, indicating a positive association of satisfaction with life and subjective vitality. This is consistent with previous research in college students [51,53,92], and thereby, these findings provide further support for the criterion validity of both instruments in higher education. All items of the SWLS and the SVS significantly discriminated university students with low self-esteem, which is considered one of the strongest indicators of life satisfaction and subjective well-being $[4,17,93]$.

Findings from the present study have a number of important implications, both for higher education context and research. First, this study contributes to the advancement of research on subjective well-being, as it offers evidence for the reliability and validity of the SWLS and the SVS, two instruments aimed to measure the cognitive and affective aspects of subjective well-being $[40,50]$. Second, these results justify the use of the SWLS and the SVS in Spanish higher education, as they have been demonstrated to be two reliable and valid instruments to measure satisfaction with life and subjective vitality, respectively. Spanish higher education institutions are becoming more interested in developing strategies aimed to nurture sustainability values in university students and society, which is leading to the creation of a sustainability specialization campus committed to environmental, economic and social sustainability [94]. Psychosocial and social sustainability are heavily associated with subjective well-being in this particular population, as college students consider that social relationships and health are the two most important factors of well-being $[1,95,96]$. Interestingly, this appreciation seems to be shared by populations from different cultural and geographical backgrounds, pointing towards a cross-cultural model regarding social sustainability and subjective well-being [34,35]. Therefore, findings from this study will allow for a more comprehensive evaluation of students' well-being and its association with social sustainability. In this respect, this study contributes to fill the gap in validation research on subjective well-being assessment in Spanish higher education. Furthermore, findings from this study can be replicated by other studies that explore subjective well-being assessment in university students and the invariance between higher education and general population. Finally, descriptive results of the SWLS and the SVS are provided, which have practical importance. Future studies can explore differences in satisfaction with life and subjective 
vitality between university students and other population groups in order to further assess subjective well-being in higher education context.

Some limitations of this study should be noted. First, the sample came from a single Spanish university, which may introduce potential bias. However, participants had different sociodemographic and academic contexts, which allowed for a more representative sample. Second, the seven-item model of the SVS could not be tested, as we used the six-item version $[46,48]$. However, it should be noted that the six-item version showed a better fit than the seven-item model in Spanish adolescents, and thereby it is the recommended version of the SVS in the Spanish population [48]. Third, measurement invariance over time or across groups was not analyzed. Further research should test the invariance over time in different groups of university students, using larger and more balanced samples, and examine the psychometric properties of the SWLS and the SVS in this population across different countries and contexts, in order to contribute to the evidence regarding subjective well-being assessment in higher education.

Sustainability has become one of the major concerns for all organizations, including higher education institutions, and has important relationships with both individual and community well-being $[22,25,94,97]$. Future research is needed to further explore this association in university students and to determine if the newly developed strategies in higher education regarding sustainability promotion have a significant effect on students' cognitive and affective well-being.

\section{Conclusions}

In summary, findings from this study support the factorial structure, internal consistency, and criterion and discriminant validity of the SWLS and the SVS in Spanish university students. These outcomes provide further evidence that these scales can effectively address cognitive and affective components of subjective well-being in higher education.

Clinical practitioners and researchers may use these freely available, brief and user-friendly instruments to measure satisfaction with life and subjective vitality in university students. The reliable and valid assessment of this population's well-being will contribute to the development of interventions and policy changes within higher education context, aiming to promote the students' well-being and personal and academic fulfillment.

Author Contributions: Conceptualization, L.D.-L., R.M.-M. and S.S.-d.-R.; methodology, L.D.-L., R.M.-M. and S.S.-d.-R.; validation, L.D.-L., R.M.-M., A.V.-P., M.-Á.T.-V., J.-M.C.-V., B.G.-G., A.Á.-Â. and S.S.-d.-R.; formal analysis, L.D.-L. and R.M.-M.; resources, L.D.-L., R.M.-M. and S.S.-d.-R.; data curation, L.D.-L. and R.M.-M.; writing-original draft preparation, L.D.-L. and R.M.-M.; writing-review and editing, L.D.-L., R.M.-M., A.V.-P., M.-Á.T.-V., J.-M.C.-V., B.G.-G., A.Á.-Á. and S.S.-d.-R.; visualization, L.D.-L., R.M.-M., A.V.-P., M.-Á.T.-V., J.-M.C.-V., B.G.-G., A.Ä.-Á. and S.S.-d.-R.; supervision, L.D.-L., R.M.-M. and S.S.-d.-R.; project administration, L.D.-L., R.M.-M. and S.S.-d.-R.; funding acquisition, J.-M.C.-V. All authors have read and agreed to the published version of the manuscript.

Funding: This research received no external funding. The APC was funded by Riazor Salud, S.L.

Acknowledgments: The authors thank the students that participated in the study and the institutional boards of University of A Coruña and Vicerrectorado del Campus de Ferrol y Responsabilidad Social for their administrative and technical support.

Conflicts of Interest: The authors declare no conflict of interest. The funders had no role in the design of the study; in the collection, analyses, or interpretation of data; in the writing of the manuscript, or in the decision to publish the results. 


\section{References}

1. Lengyel, A.; Kovács, S.; Müller, A.; Dávid, L.; Szöke, S.; Bácsné Bába, E. Sustainability and Subjective Well-Being: How Students Weigh Dimensions. Sustainability 2019, 11, 6627. [CrossRef]

2. Kobau, R.; Seligman, M.E.P.; Peterson, C.; Diener, E.; Zack, M.M.; Chapman, D.; Thompson, W. Mental Health Promotion in Public Health: Perspectives and Strategies From Positive Psychology. Am. J. Public Health 2011, 101, e1-e9.

3. Kahneman, D.; Krueger, A.B. Developments in the measurement of subjective well-being. J. Econ. Perspect. 2006, 20, 3-24.

4. Diener, E. Subjective well-being. Psychol. Bull. 1984, 95, 542-575. [PubMed]

5. Diener, E. Subjective well-being. The science of happiness and a proposal for a national index. Am. Psychol. 2000, 55, 34-43. [CrossRef] [PubMed]

6. Diener, E. Happiness. In Handbook of Individual Differences in Social Behavior; Leary, M.R., Hoyle, R.H., Eds.; Guilford: New York, NY, USA, 2004; pp. 147-160.

7. Diener, E.; Ryan, K. Subjective Well-Being: A General Overview. S. Afr. J. Psychol. 2009, 39, 391-406.

8. Watson, D.; Clark, L.A.; Tellegen, A. Development and validation of brief measures of positive and negative affect: The PANAS scales. J. Personal. Soc. Psychol. 1988, 54, 1063-1070. [CrossRef]

9. Myers, D.G.; Diener, E. Who Is Happy? Psychol. Sci. 1995, 6, 10-17. [CrossRef]

10. Tay, L.; Kuykendall, L.; Diener, E. Satisfaction and happiness. The bright side of quality of life. In Global Handbook of Quality of Life. Exploration of Well-Being of Nations and Continents; Glatzer, W., Camfield, L., Moller, V., Rojar, M., Eds.; Springer: Dordrecht, The Netherlands, 2015; pp. 839-853.

11. Medvedev, O.N.; Landhuis, C.E. Exploring constructs of well-being, happiness and quality of life. Peer J. 2018, 6, e4903. [CrossRef]

12. Diener, E.; Chan, M.Y. Happy People Live Longer: Subjective Well-Being Contributes to Health and Longevity. Appl. Psychol. Health Well Being 2011, 3, 1-43.

13. Kansky, J.; Allen, J.P.; Diener, E. Early Adolescent Affect Predicts Later Life Outcomes. Appl. Psychol. Health Well Being 2016, 8, 192-212. [CrossRef] [PubMed]

14. Zhang, Z.; Chen, B.; Chen, W. The mediating effect of perceived health on the relationship between physical activity and subjective well-being in Chinese college students. J. Am. Coll. Health 2019, 22, 1-8. [CrossRef] [PubMed]

15. Cachón Zagalaz, J.; López Manrique, I.; San Pedro Veledo, M.B.; Zagalaz Sánchez, M.L.; González González de Mesa, C. The Importance of the Phoenix Bird Technique (Resilience) in Teacher Training: CD-RISC Scale Validation. Sustainability 2020, 12, 1002. [CrossRef]

16. Lew, B.; Huen, J.; Yu, P.; Yuan, L.; Wang, D.F.; Ping, F.; Abu Talib, M.; Lester, D.; Jia, C.X. Associations between depression, anxiety, stress, hopelessness, subjective well-being, coping styles and suicide in Chinese university students. PLoS ONE 2019, 14, e0217372. [CrossRef] [PubMed]

17. Duy, B.; Yıldız, M.A. The Mediating Role of Self-Esteem in the Relationship between Optimism and Subjective Well-Being. Curr. Psychol. 2019, 38, 1456-1463. [CrossRef]

18. Keane, L.; Loades, M. Low self-esteem and internalizing disorders in young people-A systematic review. Child Adolesc. Ment. Health 2017, 22, 4-15. [CrossRef]

19. Membiela-Pollán, M.; Alló-Pazos, M.; Pateiro-Rodríguez, C.; Blázquez-Lozano, F. The Inefficiency of the Neoclassical Paradigm in the Promotion of Subjective Well-Being and Socioeconomic, and Environmental Sustainability: An Empirical Test for the Spanish Case. Sustainability 2019, 11, 7102. [CrossRef]

20. Amrutha, V.N.; Geetha, S.N. A systematic review on green human resource management: Implications for social sustainability. J. Clean. Prod. 2019, 247, 119131. [CrossRef]

21. Haller, M.; Hadler, M. How social relations and structures can produce happiness and unhappiness: An international comparative analysis. Soc. Indic. Res. 2006, 75, 169-216. [CrossRef]

22. Furchheim, P.; Martin, C.; Morhart, F. Being green in a materialistic world: Consequences for subjective well-being. Psychol. Mark. 2020, 37, 114-130. [CrossRef]

23. Munzel, A.; Meyer-Waarden, L.; Galan, J.P. The social side of sustainability: Well-being as a driver and an outcome of social relationships and interactions on social networking sites. Technol. Forecast. Soc. 2018, 130, 14-27. [CrossRef]

24. Mouratidis, K. Compact city, urban sprawl, and subjective well-being. Cities 2019, 92, 261-272. [CrossRef] 
25. Musa, H.D.; Yacob, M.R.; Abdullah, A.M.; Ishak, M.Y. Enhancing subjective well-being through strategic urban planning: Development and application of community happiness index. Sustain. Cities Soc. 2018, 38, 184-194. [CrossRef]

26. Scott, H.; Takarangi, M.K.T. Measuring PhD Students' Well-being: Are we Seeing the Whole Picture? Stud. Success 2019, 10, 14-24. [CrossRef]

27. Cvetkovski, S.; Reavley, N.J.; Jorm, A.F. The prevalence and correlates of psychological distress in Australian tertiary students compared to their community peers. Aust. N. Z. J. Psychiatry 2012, 46, 457-467. [CrossRef] [PubMed]

28. Eisenberg, D.; Hunt, J.; Speer, N. Mental health in American colleges and universities: Variation across student subgroups and across campuses. J. Nerv. Ment. Dis. 2013, 201, 60-67. [CrossRef]

29. Sletta, C.; Tyssen, R.; Lovseth, L.T. Change in subjective well-being over 20 years at two Norwegian medical schools and factors linked to well-being today: A survey. BMC Med. Educ. 2019, 19, 45. [CrossRef]

30. Newcomb-Anjo, S.; Villemaire-Krajden, R.; Takefman, K.; Barker, E.T. The unique associations of university experiences with depressive symptoms in emerging adulthood. Emerg. Adulthood 2017, 5, 75-80. [CrossRef]

31. Samaranayake, C.B.; Arroll, B.; Fernando, A.T. Sleep disorders, depression, anxiety and satisfaction with life among young adults: A survey of university students in Auckland, New Zealand. N. Z. Med. J. 2014, 127, 13-22.

32. Freire, C.; Ferradás, M.M.; Núñez, J.C.; Valle, A.; Vallejo, G. Eudaimonic Well-Being and Coping with Stress in University Students: The Mediating/Moderating Role of Self-Efficacy. Int. J. Environ. Res. Public Health 2019, 16, 48. [CrossRef]

33. Moors, G. The two faces of (post) materialism: A decomposition approach. Int. J. Public Opin. Res. 2003, 15, 396-412. [CrossRef]

34. Delle Fave, A.; Brdar, I.; Wissing, M.P.; Araujo, U.; Castro Solano, A.; Freire, T.; Nakamura, J. Lay definitions of happiness across nations: The primacy of inner harmony and relational connectedness. Front. Psychol. 2016, 7, 30. [CrossRef] [PubMed]

35. Lamu, A.N.; Olsen, J.A. The relative importance of health, income and social relations for subjective well-being: An integrative analysis. Soc. Sci. Med. 2016, 152, 176-185. [CrossRef] [PubMed]

36. Botha, B.; Mostert, K.; Jacobs, M. Exploring indicators of subjective well-being for first-year university students. J. Psychol. Afr. 2019, 29, 480-490. [CrossRef]

37. Vázquez, C.; Duque, A.; Hervás, G. Satisfaction with life scale in a representative sample of Spanish adults: Validation and normative data. Span. J. Psychol. 2013, 16, 1-15. [CrossRef] [PubMed]

38. Serban-Oprescu, G.-L.; Dedu, S.; Serban-Oprescu, A.-T. An Integrative Approach to Assess Subjective Well Being. A Case Study on Romanian University Students. Sustainability 2019, 11, 1639. [CrossRef]

39. Pavot, W.; Diener, E. The affective and cognitive contest of self reports measurements of subjective well-being. Soc. Indic. Res. 1993, 28, 1-20. [CrossRef]

40. Diener, E.; Emmons, R.A.; Larse, R.J.; Griffin, S. The satisfaction with life scale. J. Personal. Assess. 1985, 49, 71-75. [CrossRef]

41. Esnaola, I.; Benito, M.; Antonio-Agirre, I.; Freeman, J.; Sarasa, M. Measurement invariance of the Satisfaction with Life Scale (SWLS) by country, gender and age. Psicothema 2017, 29, 596-601.

42. Pavot, W.; Diener, E.; Colvin, C.R.; Sandvik, E. Further validation of the Satisfaction with Life Scale: Evidence for the cross-method convergence of well-being. J. Personal. Assess. 1991, 57, 149-161. [CrossRef]

43. Pavot, W.; Diener, E. Review of the Satisfaction with Life Scale. In Assessing Well-Being; Diener, E., Ed.; Springer: Berlin/Heidelberg, Germany, 2009; pp. 101-117.

44. Bai, X.; Wu, C.; Zheng, R.; Xiaopeng, R. The psychometric evaluation of the Satisfaction with Life Scale using a nationally representative sample of China. J. Happiness Stud. 2011, 12, 183-197. [CrossRef]

45. Glaesmer, H. The German Version of the Satisfaction with Life Scale (SWLS). Eur. J. Psychol. Assess. 2011, 27, 127-132. [CrossRef]

46. Atienza, F.L.; Pons, D.; Balaguer, I.; García-Merita, M.L. Propiedades psicométricas de la Escala de Satisfacción con la Vida en adolescents. Psicothema 2000, 12, 331-336.

47. Atienza, F.L.; Balaguer, I.; García-Merita, M.L. Satisfaction with Life Scale: Analysis of factorial invariance across sexes. Personal. Individ. Differ. 2003, 35, 1255-1260. [CrossRef]

48. Pons, D.; Atienza, F.L.; Balaguer, I.; García-Merita, M.L. Satisfaction with Life Scale: Analysis of factorial invariance for adolescents and elderly persons. Percept. Mot. Ski. 2000, 91, 62-68. [CrossRef] 
49. Atienza González, F.L.; Balaguer Solá, I.; Corte-Real, N.; Fonseca, A.M. Factorial invariance of the Satisfaction with Life Scale in adolescents from Spain and Portugal. Psicothema 2016, 28, 353-358. [PubMed]

50. Ryan, R.M.; Frederick, C.M. On energy, personality and health: Subjective vitality as a dynamic reflection of well-being. J. Personal. 1997, 65, 529-565. [CrossRef]

51. Çelik, E. Examining the mediating effect of subjective vitality in the proactive personality and life satisfaction relationship. Int. J. Happiness Dev. 2017, 3, 289-302. [CrossRef]

52. Jan, W.E.; Bucy, E.P.; Cho, J. Self-esteem moderates the influences of self-presentation style on Facebook users' sense of subjective well-being. Comput. Hum. Behav. 2018, 85, 190-199.

53. Salama-Younes, M. Positive mental health, subjective vitality, and satisfaction with life for French physical education students. World J. Sport Sci. 2011, 4, 90-97.

54. Barrantes-Brais, K.; Kelley, G.; Sánchez-Ureña, B. Physical Activity Levels and Psychological Well-being/Ill-being in Costa Rican College Students. Med. Sci. Sports Exerc. 2017, 49, 471-472. [CrossRef]

55. Xie, H.; Guan, S.S.A.; Boyns, D. Use of a Student Recreation Center, Self-Determination Needs Satisfaction, and Subjective Vitality: A Structural Model. Recreat. Sports J. 2018, 42, 116-129. [CrossRef]

56. Jurado, P.J.; Soto, M.C.; Conchas, M.; Nájera, R.J. Estructura Factorial de la Escala de Satisfacción con la Vida de Diener en Universitarios Mexicanos. Form. Univ. 2019, 12, 183-190. [CrossRef]

57. Bostic, T.J.; Rubio, D.M.; Hood, M. A validation of the subjective vitality scale using structural equation modeling. Soc. Indic. Res. 2000, 52, 313-324. [CrossRef]

58. Kawabata, M.; Yamazaki, F.; Guo, D.W.; Chatzisarantis, N.L.D. Advancement of the Subjective Vitality Scale: Examination of alternative measurement models for Japanese and Singaporeans. Scand. J. Med. Sci. Sports 2017, 27, 1793-1800. [CrossRef]

59. Castillo, I.; Tomás, I.; Balaguer, I. The Spanish-Version of the Subjective Vitality Scale: Psychometric Properties and Evidence of Validity. Span. J. Psychol. 2017, 20,1-8. [CrossRef]

60. Vera-Villarroeal, P.; Urzúa, A.M.; Celis-Atenas, P.P.K.; Silva, J. Evaluation of Subjective Well-being: Analysis of the Satisfaction with Life Scale in Chilean Population. Univ. Psychol. 2012, 11, 719-727. [CrossRef]

61. López-Ortega, M.; Torres-Castro, S.; Rosas-Carrasco, O. Psychometric properties of the Satisfaction with Life Scale (SWLS): Secondary analysis of the Mexican Health and Aging Study. Health Qual. Life Outcomes 2016, 14, 170. [CrossRef]

62. Cardenas Castro, M.; Barrientos Delgado, J.; Bilbao Ramirez, A.; Gomez Ojeda, D.P.R.F.; Asun Salazar, D. Estructura Factorial de la Escala de Satisfacción con la Vida en una muestra de estudiantes universitarios chilenos [Factorial structure of the Satisfaction with Life Scale in a Chilean University Sample]. Rev. Mex. Piscol. 2012, 29, 157-164.

63. Koo, J. Measurement Invariance of the Satisfaction with Life Scale (SWLS) across Age and Gender in Korea. Korean Psychol. J. Cult. Soc. Issues 2019, 25, 305-323. [CrossRef]

64. Wolf, E.J.; Harrington, K.M.; Clark, S.L.; Miller, M.W. Sample Size Requirements for Structural Equation Models: An Evaluation of Power, Bias and Solution Propriety. Educ. Psychol. Meas. 2013, 76, 913-934. [CrossRef] [PubMed]

65. Rosenberg, M. Society and the Adolescent Self-Image; Princeton University Press: Princeton, NJ, USA, 1965.

66. Martín-Albo, J.; Núñiez, J.L.; Navarro, J.G.; Grijalvo, F. The Rosenberg Self-Esteem Scale: Translation and validation in university students. Span. J. Psychol. 2007, 10, 458-467. [CrossRef] [PubMed]

67. Isomaa, R.; Väänänen, J.M.; Fröjd, S.; Kaltiala-Heino, R.; Marttunen, M. How low is low? Low self-sesteem as an indicator of internalizing psychopathology in adolescence. Health Educ. Behav. 2013, 40, 392-399. [CrossRef]

68. Forero, C.G.; Maydeu-Olivares, A.; Gallardo-Pujol, D. Factor analysis with ordinal indicators: A monte carlo study comparing DWLS and ULS estimation. Struct. Equ. Modeling 2009, 16, 625-641. [CrossRef]

69. Yang-Wallentin, F.; Jöreskog, K.G.; Luo, H. Confirmatory factor analysis of ordinal variables with misspecified models. Struct. Equ. Modeling 2010, 17, 392-423. [CrossRef]

70. West, S.G.; Finch, J.F.; Curran, P.J. Structural equation models with non-normal variables. In Structural Equation Modeling: Concepts, Issues and Applications; Hoyle, R.H., Ed.; Sage: Thousand Oaks, CA, USA, 1995; pp. 56-75.

71. Hu, L.T.; Bentler, P.M. Cutoff criteria for fit indexes in covariance structure analysis: Conventional criteria versus new alternatives. Struct. Equ. Modeling 1999, 6, 1-55. [CrossRef] 
72. Kline, R.B. Principles and Practice of Structural Equation Modeling, 2nd ed.; Guilford Press: New York, NY, USA, 2005.

73. Joreskog, K.G.; Sorbom, D. LISREL 8: Structural Equation Modeling with the SIMPLIS Command Language; Lawrence Erlbaum Associates Publishers: Hilldale, NJ, USA, 1993.

74. Byrne, B.M. Structural Equation Modeling with EQS and EQS-Windows: Basic Concepts, Applications and Programing; SAGE: Thousand Oaks, CA, USA, 1994.

75. Browne, M.W.; Cudeck, R. Alternative Ways of Assessing Model Fit. Soc. Methods Res. 1992, 21, $230-258$. [CrossRef]

76. Liu, J.-D.; Chung, P.-K. Factor structure and measurement invariance of the Subjective Vitality Scale: Evidence from Chinese adolescents in Hong Kong. Qual. Life Res. 2019, 28, 233-239. [CrossRef]

77. Trochim, W.M.; Donnelly, J.P. The Research Methods Knowledge Base, 3rd ed.; Atomic Dog Publishing: Cincinnati, OH, USA, 2006.

78. Field, A. Discovering Statistics Using SPSS, 5th ed.; SAGE: London, UK, 2017.

79. Gravetter, F.; Wallnau, L. Essentials of Statistics for the Behavioral Sciences, 8th ed.; Wadsworth: Belmont, TN, USA, 2014.

80. Di Fabio, A.; Gori, A. Measuring Adolescent Life Satisfaction: Psychometric Properties of the Satisfaction with Life Scale in a Sample of Italian Adolescents and Young Adults. J. Psychoeduc. Assess. 2016, 34, 501-506. [CrossRef]

81. Anaby, D.; Jarus, T.; Zumbo, B.D. Psychometric Evaluation of the Hebrew Language Version of the Satisfaction with Life Scale. Soc. Indic. Res. 2010, 96, 267-274. [CrossRef]

82. Vela, J.C.; Lerma, E.; Ikonomopoulos, J. Evaluation of the Life Satisfaction and Subjective Happiness Scales with Mexican American High School and College Students. Hisp. J. Behav. Sci. 2017, 39, 34-45. [CrossRef]

83. Sovet, L.; Atitsogbe, K.A.; Pari, P.; Park, M.S.A.; Villieux, A. Psychometric evaluation of the satisfaction with life scale in Togo: A three-step approach. Eur. Rev. Appl. Psychol. 2016, 66, 243-250. [CrossRef]

84. Navrátil, M.; Lewis, C.A. Temporal Stability of the Czech Translation of the Satisfaction with Life Scale: Test-Retest Data over One Week. Psychol. Rep. 2006, 98, 918-920. [CrossRef] [PubMed]

85. Gouveia, V.V.; Milfont, T.L.; Nunes da Fonseca, P.; Peçanha de Miranda Coelho, J.A. Life Satisfaction in Brazil: Testing the Psychometric Properties of the Satisfaction with Life Scale (SWLS) in Five Brazilian Samples. Soc. Indic. Res. 2009, 90, 267-277. [CrossRef]

86. Zanon, C.; Bargadi, M.P.; Layous, K.; Hutz, C.S. Validation of the Satisfaction with Life Scale to Brazilians: Evidences of Measurement Noninvariance across Brazil and US. Soc. Indic. Res. 2014, 119, 443-453. [CrossRef]

87. Durak, M.; Senol-Durak, E.; Gencoz, T. Psychometric Properties of the Satisfaction with Life Scale among Turkish University Students, Correctional Officers, and Elderly Adults. Soc. Indic. Res. 2010, 99, 413-429. [CrossRef]

88. Molina-García, J.; Castillo, I.; QUeralt, A. Leisure-Time Physical Activity and Psychological Well-Being in University Students. Psychol. Rep. 2011, 109, 453-460. [CrossRef]

89. Taylor, I.M.; Lonsdale, C. Cultural differences in the relationships among autonomy support, psychological need satisfaction, subjective vitality, and effort in British and Chinese physical education. J. Sport Exerc. Psychol. 2010, 32, 655-673. [CrossRef]

90. Liu, J.; Bartholomew, K.; Chung, P.-K. Perceptions of Teachers' Interpersonal Styles and Well-Being and Ill-Being in Secondary School Physical Education Students: The Role of Need Satisfaction and Need Frustration. Sch. Ment. Health 2017, 9, 360-371. [CrossRef]

91. Kenny, D.A.; Kaniskan, B.; McCoach, D.B. The performance of RMSEA in models with small degrees of freedom. Sociol. Methods Res. 2015, 44, 486-507. [CrossRef]

92. Uysal, R.; Satici, S.A.; Satici, B.; Akin, A. Subjective Vitality as Mediator and Moderator of the Relationship between Life Satisfaction and Subjective Happiness. Educ. Sci. Theory Pract. 2014, 14, 489-497. [CrossRef]

93. Pu, J.; Hou, H.; Ma, R. The Mediating Effects of Self-Esteem and Trait Anxiety Mediate on the Impact of Locus of Control on Subjective Well-Being. Curr. Psychol. 2017, 36, 167-173. [CrossRef]

94. Universidade da Coruña. Memoria De Responsabilidad Social Universidade Da Coruña 2017-2018. Construyendo El Future Desde La Colaboración Con La Empresa y La Igualdad De Oportunidades; Universidade da Coruña: A Coruña, Spain, 2019.

95. Wang, J.L.; Jackson, L.A.; Gaskin, J.; Wang, H.Z. The effects of Social Networking Site (SNS) use on college students' friendship and well-being. Comput. Hum. Behav. 2014, 37, 229-236. [CrossRef] 
96. Harris, K.; English, T.; Harms, P.D.; Gross, J.J.; Jackson, J.J. Why are extraverts more satisfied? Personality, social experiences, and subjective well-being in college. Eur. J. Pers. 2017, 31, 170-186. [CrossRef]

97. Olawumi, T.O.; Chan, D.W. A scientometric review of global research on sustainability and sustainable development. J. Clean. Prod. 2018, 183, 231-250. [CrossRef]

(C) 2020 by the authors. Licensee MDPI, Basel, Switzerland. This article is an open access article distributed under the terms and conditions of the Creative Commons Attribution (CC BY) license (http://creativecommons.org/licenses/by/4.0/). 